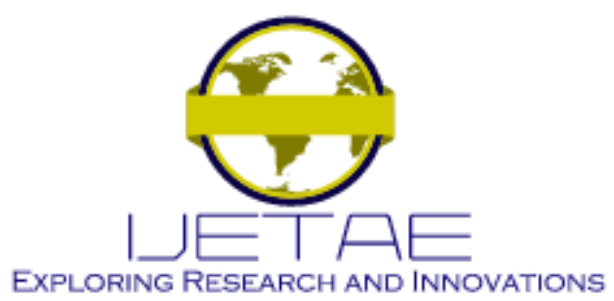

International Journal of Emerging Technology and Advanced Engineering

Website: www.ijetae.com (E-ISSN 2250-2459, Scopus Indexed, ISO 9001:2008 Certified Journal, Volume 11, Issue 11, November 2021)

Manuscript Received: 09 October 2021, Received in Revised form:04 November 2021, Accepted: 12 November 2021

DOI: $10.46338 /$ ijetae1121_16

\title{
Prototype of a System for Quail Farming with Arduino Nano Platform, DHT11 and LM35 Sensors, in Arequipa, Peru
}

\author{
Sebastian Ramos-Cosi ${ }^{1}$, Natalia I. Vargas-Cuentas ${ }^{2}$ \\ ${ }^{1,2}$ Image Processing Research Laboratory (INTI-Lab), Universidad de Ciencias y Humanidades (UCH), Lima, Perú
}

\begin{abstract}
Quail farming ranks 3rd at the national level for poultry production and has growth projections of $3.9 \%$ in the coming years. In Peru, due to the decreases in temperature and cold in the southern part of the country, it presents a significant problem to the development of quail farms, of which its primary derivative is the egg that provides food contributions to the population and only with the $18.1 \%$ cholesterol compared to the eggs of other birds. This study aims to develop an automatic farm system to increase the production in the laying stage of quails in the homes of Arequipa. The control system was developed with the Arduino Nano platform, DHT11, LM35 sensors, actuators such as a $25 \mathrm{~W}$ bulb, a fan, and a humidifier, which allow continuous temperature and humidity control. In addition, all the variables can be visualized through an LCD screen. A simple 3D model was developed with a capacity of between 10 and 25 quails. In charge of the control processes, the Arduino module reached an error rate of $0.9 \%$ in the temperature variable, and the humidity variable does not present an error rate. The total power of the prototype was measured and converted into a monetary value. Average power of $\mathbf{0 . 0 2 6 6 7}$ $\mathrm{kW}$ / hour was obtained, which is reflected in a saving of 82.22\% compared to using a $100 \mathrm{~W}$ bulb.
\end{abstract}

Keywords - Poultry production, farm quail, quail egg, automation, Arduino.

\section{INTRODUCTION}

Among the primary economic income of Peru are agricultural exports, which registered a historical record of US $\$ 6,817$ million in 2020 and a growth of $3.9 \%$ is projected for 2024 [1] and which ranks 3rd in poultry production [2] within which is the quail farming, which does not have a significant investment. On the other hand, in the southern region of Peru, there are climatic phenomena characterized by the abrupt decrease in temperature [3] [4], and the city of Arequipa does not escape this phenomenon [5] [6]. That is why quail farming is reduced in this region of the country.
In addition, according to many investigations [7] - [10], quail derivatives present an important nutritional contribution to health, especially quail eggs, which contain only $18.1 \%$ of the cholesterol that chicken eggs would contain [11]. What is more, consuming one quail egg a day is not detrimental to cardiovascular health [9].

Systems applied to quail have been developed intermittently. According to the study in [12], an incubator for quail eggs was designed. Its main objective is to achieve the highest amount of hatching in the eggs. For this purpose, the Arduino platform and humidity and temperature sensors were used. The incubator managed to incubate 490 eggs in 17 days with a success of $87.55 \%$.

On the other hand, in [13], it was indicated the vital role in the automation of poultry farms. In this research, a monitoring system with IoT for poultry farms was developed; an electricity supply from manure was also implemented. The results obtained were the control of the farm through a web page and an efficiency of approximately $86 \%$.

However, the design of an autonomous farm has a significant disadvantage: the cost of manufacture. In [14], the development of a quail hatchery prototype is detailed to improve egg production through sensors and metal structures, using Arduino Mega 2560. It also indicates that the design of its autonomous quail farm is economically solvent after two years of constant production.

The problem lies in the inadequate training of quail rearing, and most of the studies consulted work with similar technologies. However, these studies are focused on chicken egg incubators or control designs applied to greenhouses.

As previously observed, it is important to develop tools that can contribute to the increase of quail farming in the country and seek to reduce animal mortality due to the cold wave in southern Peru and strengthen the nutritional value of low-income families in the country. 


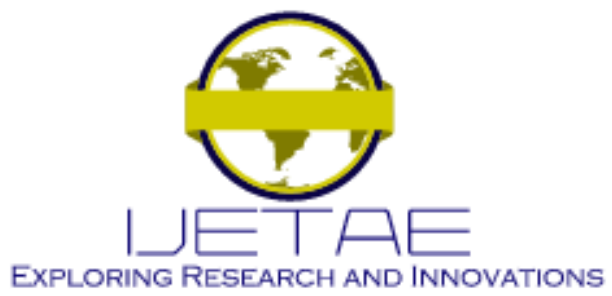

International Journal of Emerging Technology and Advanced Engineering

Website: www.ijetae.com (E-ISSN 2250-2459, Scopus Indexed, ISO 9001:2008 Certified Journal, Volume 11, Issue 11, November 2021)

In this sense, the present research aims to develop a lowcost automated quail farm to increase the production of quail eggs in the laying stage in a region vulnerable to cold such as Arequipa.

The present study will develop an automatic system for a domestic farm using the Arduino platform, mainly controlling the temperature and humidity parameters through the DHT11 humidity sensor and the LM35 temperature sensor. The user will control all variables through an LCD screen to modify the farm's operating time, according to the bird's needs, whether for continuous use or only at night. In addition, the sensors used are lowcost with a working voltage compatible with the Arduino platform.

The present work is structured as follows; in section II, the methodology for developing the prototype is described in greater detail. In section III, the results obtained are evidenced, and finally, in section IV, the results, conclusions and future work of the project are discussed.

\section{Methods And MAterials}

The prototype implemented in homes to promote quail breeding collects and monitors variables essential for the health and correct development of the bird..

\section{A. Description of the bird}

The quail (Coturnix Coturnix Japonica) is a bird from Asia, Europe and Africa. This bird adapts to a sedentary life which allows its exploitation in short spaces. Its dimensions range between 16 and $22 \mathrm{~cm}$ with an average weight of 120 grams [15]. The bird's plumage is oval with reddish-brown and yellow colors [16]. The predominant sexual difference is sexual dimorphism that occurs after 15 days of life [17], where the female is also more prominent than the male. The sense of vision has a significant development; however, hearing sensitivity is lower than other birds and mammals.

The growth stages in the quail start from the egg position, which after 17 days of incubation, the quail chick is born [18]. At 21 days, the bird begins to show its sexual characteristics, and on average, at 43 days, they reach sexual maturity [19], [20]. The average life span is more than two years. However, its egg production period only maintains stability during the first year of laying. To develop this prototype, we will focus from the maturity of the bird until its last incubation period.

\section{B. Study area}

The study area is located at 2335 m.a.s.l. in the province of Arequipa, Peru. This area belongs to the low mountainous zone, with a temperate climate in the summer to intense cold in winter [21], with an annual mean temperature between $7.0^{\circ} \mathrm{C}$ and $23.2^{\circ} \mathrm{C}$ [22]. The region is not very mountainous and is constantly affected by frosts [3]. In addition, the high population density index favours the application of the prototype due to the number of households that exist in this region [23].

\section{General diagram of the system}

The operation of the prototype responds to a closed control system, where the sensors inside the quail cage give feedback. The block diagram of the prototype can be seen in sequence in Fig 1:

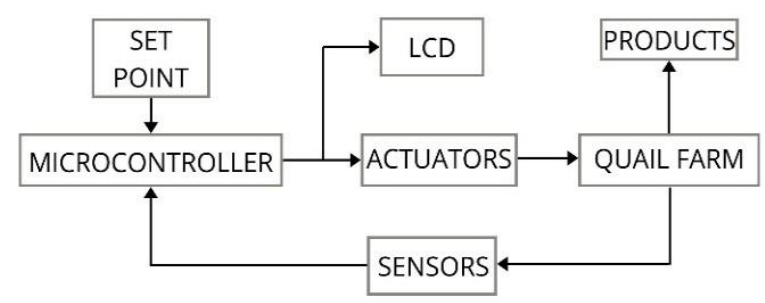

Fig. 1. Block diagram of the system

When the system is turned on, the temperature and humidity levels that the bird needs are established. The sensed values will be displayed on the LCD screen, and as determined by the system, the actuators will start operating. The quail farm, when controlled, will offer the user the final product, which is the quail egg. The parameters estimated by the setpoint will be the ideal ones to prevent the bird from becoming stressed or entering the plumage period.

\section{Components and equipments}

Once the study area and the prototype design had been established, it was intended to define variables with the respective electronic components to be used. However, it was necessary to define the typology of the components. In this case, the Arduino platform was used, with the Arduino Nano v3.0 model, which has the Atmega 328p microcontroller [24]. 


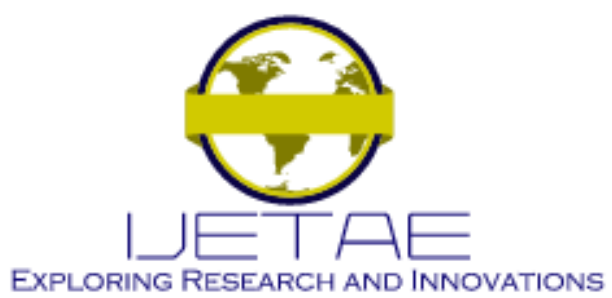

International Journal of Emerging Technology and Advanced Engineering

Website: www.ijetae.com (E-ISSN 2250-2459, Scopus Indexed, ISO 9001:2008 Certified Journal, Volume 11, Issue 11, November 2021)

This Arduino has adequate processing capacity to maintain the system. The definition of the electronic components of the prototype is shown in Table 1. The objective of this operation is to recognize the capacity of the microcontroller with the various inputs and outputs, in addition to the respective plug and play modules, which economize on the prototype design [25], [26] and makes the design of the proposed solution more compact.

TABLE 1.

DESCRIPTION OF THE ELECTRONICS COMPONENTS

\begin{tabular}{|c|c|c|}
\hline Component & Name & Description \\
\hline 1 & $\begin{array}{l}\text { Arduino Nano } \\
\text { v3.0 }\end{array}$ & $\begin{array}{l}\text { Recommended operating } \\
\text { voltage } 7-12 \mathrm{v}, 14-\text { pin } \\
\text { digital input / output, } 7 \\
\text { analog pin and } \\
\text { comunication I2C. }\end{array}$ \\
\hline 2 & $\begin{array}{l}\text { Temperature } \\
\text { sensorLm35 }\end{array}$ & $\begin{array}{l}\text { Recommended voltage } 3- \\
5.5 \mathrm{v} \text {. Analog output } 10 \mathrm{mv} \\
/ \mathrm{c}^{\circ} \text {. }\end{array}$ \\
\hline 3 & $\begin{array}{c}\text { Humidity } \\
\text { sensor DHT11 }\end{array}$ & $\begin{array}{l}\text { Recommended voltage } 3- \\
5.5 \mathrm{v} \text { - Digital output } \\
\text { humidity } \pm \quad 0.5 \% \text {, } \\
\text { temperature } 0-50{ }^{\circ} \mathrm{C} .\end{array}$ \\
\hline 4 & Relay module & $\begin{array}{l}\text { Working voltage } 5 \mathrm{v} \text {, } \\
\text { output } 250 \mathrm{v} 10 \mathrm{~A} .\end{array}$ \\
\hline 5 & Fan & $\begin{array}{l}\text { Working voltage } 5 \mathrm{v} \text {, } \\
60 \times 60 \times 10 \mathrm{~mm} .\end{array}$ \\
\hline 6 & LCD $14 \times 2$ & $\begin{array}{l}\text { Voltaje de trabajo } 5 \mathrm{v}, \\
\text { resolución de } 28 \text { caracteres } \\
\text { alfanuméricos } \\
\text { comunicación } \mathrm{I} 2 \mathrm{C} \text {. }\end{array}$ \\
\hline 7 & Humidifier & $\begin{array}{l}\text { Nano mist sprayer, wáter } \\
\text { tank capacitu } 30 \mathrm{ml} \text { and } \\
\text { working voltaje } 5 \mathrm{v} \text {. }\end{array}$ \\
\hline
\end{tabular}

As can be seen in Table 1, in total, there are two sensors and three actuators. To this is added the I2C module for communication with the LCD. In other words, a digital input, an analogue input for the sensors and three outputs in on/off mode will be required. All of them are compatible with the Arduino platform.

As actuators, a 220v ceramic light bulb was taken into account, which is a commercial product, easily accessible and which will induce heat to the farm. On the other hand, a fan of $5 \mathrm{v}$ at $200 \mathrm{~mA}$ avoids using an additional power supply, which regulates the airflow or decrease in temperature and finally, a $5 \mathrm{v}$ humidifier module for humidity control.

\section{E. 3D structure design}

After choosing appropriate components for the prototype, a 3D design was made to obtain a general visualization of the location of the sensors and actuators. Furthermore, Fig. 2 shows the design made with the free software Autodesk TinkerCad, which, as indicated in [27], is considered one of the most versatile options.

This base frame design approximates a small cage with a minimum capacity of 10 quails up to 25 quails. Besides, an upper block is added that isolates the electronic components. At the same time, the actuators are integrated at a higher height than the bird. Also, sensors are established in the cage middle part to obtain precise values in the environment close to the quail.

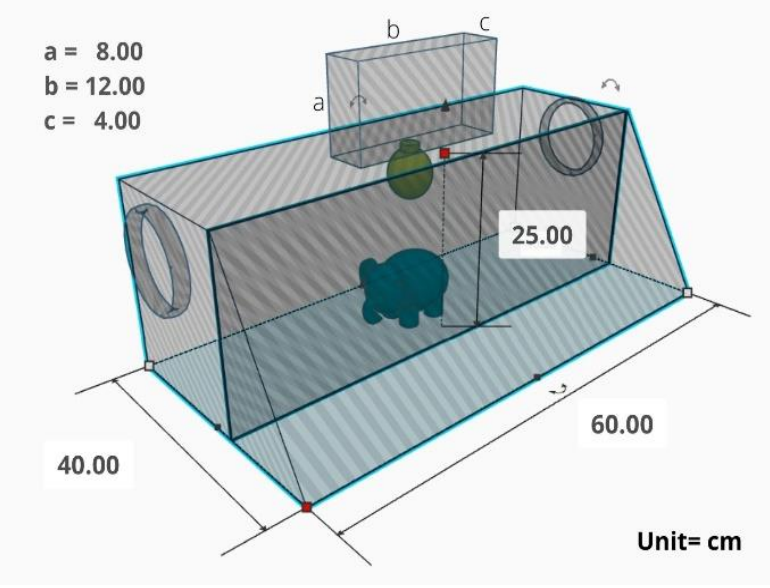

Fig. 2. 3D Design of the Prototype in TinkerCad 3D.

Moreover, the structural design of the mechanical components such as the fan supports, sockets and structures that will contain the hardware are referential because there is no library of the devices used, such as the Arduino nano v3 platform 0 . It is essential to mention that the corresponding dimensions in the image are adapted to the maximum height that a quail can reach with an approximate free space of $5 \mathrm{~cm}$. In addition to that, the designed area will be able to house around 20 to 25 quails in optimal conditions to generate ideal temperature conservation.

Finally, it is important to mention that the construction of the structure for the quail cage must consider the use of thermal materials, which is why wood is considered an economic, thermal element and not harmful to the health of the quail. 


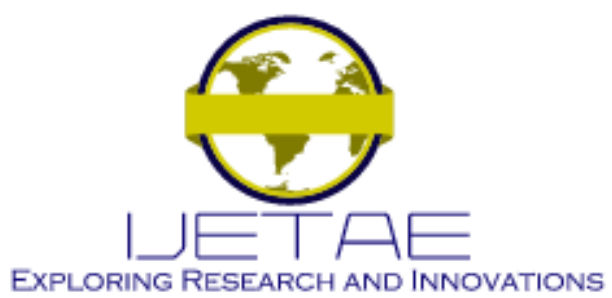

International Journal of Emerging Technology and Advanced Engineering

Website: www.ijetae.com (E-ISSN 2250-2459, Scopus Indexed, ISO 9001:2008 Certified Journal, Volume 11, Issue 11, November 2021)

\section{F. Electronic programming and design}

The Arduino platform is characterized by its versatility of programming language and IDE [28]. However, beyond a simple control program, it is necessary to know these control actions towards the prototype reliably. The most common system to understand the robustness of control tasks is to rely on tools such as Grafcet representations or a flow chart [29]. The present work is supported by a flow diagram Fig. 3. The diagram begins by defining the default variables: the temperature at a setpoint of $28{ }^{\circ} \mathrm{C}$ and the humidity between $50 \%$ and $70 \%$. Afterwards, the variables are shown to the user on the LCD. Besides, the variables are registered through the sensors to be later compared with the setpoint values. Depending on the case, one or the other actuator will be activated. If the system is within the correct parameters, the system will go into a waiting period in order not to bother the bird with the constant activations of the actuators.

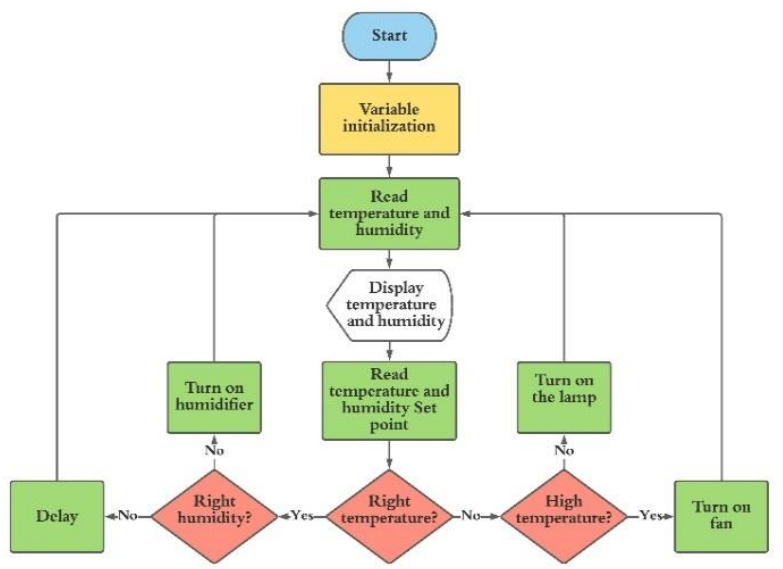

Fig. 3. Diagram flow of the algorithm

Once the instructions were modelled, the respective programming was developed using the Arduino IDE [28], whose programming environment allows the integration of libraries and direct instructions to the Atmega 328p microcontroller [30]. This programming is applied to quail farming throughout the laying stage of the bird. This algorithm controls the temperature and humidity parameters aimed at maintaining the bird's posture. The objective of controlling these variables is to avoid stress by temperature, which can severely damage the bird's posture [31].

\section{RESULTS}

The implemented prototype of the quail farm can be seen in Fig. 4. The left part shows the electronic parts in charge of keeping the farm in optimal conditions for the quail's laying. The structure of the Medium Density Fibreboard (MDF) is shown on the right side. A glass panel was fitted to view the quail, at the same time, which serves as a door to extract the bird's eggs and provide them with food and water.

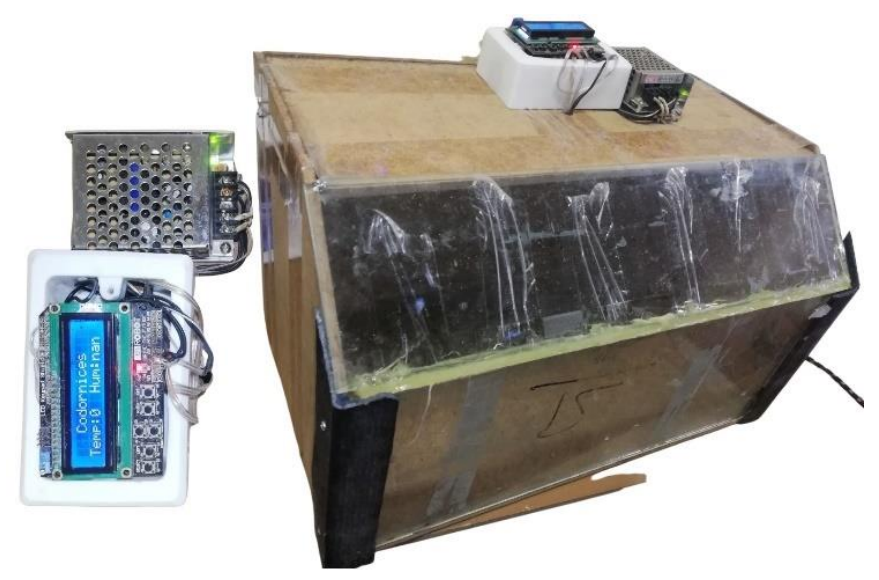

Fig. 4. 3D Design of the Prototype in TinkerCad 3D.

For the validation of the prototype, temperature measurements were made in an elapsed time of 8 hours. Table 2 shows all the temperature values obtained. In cold conditions for the first 3 hours, indicated with the letter C. Subsequently, a temperature increase is observed in the following 6 hours, indicated with the letter $M$ for temperate environmental conditions, and finally, a temperature drop is observed in the last 3 hours.

TABLE 2.

Measured Temperature CONDITIONS

\begin{tabular}{|c|c|c|c|c|}
\hline \multirow{4}{*}{ Sensor } & $\begin{array}{c}\text { Environmental } \\
\text { condition }\end{array}$ & $\begin{array}{c}\text { Tim } \\
\mathbf{e}\end{array}$ & $\begin{array}{c}\text { Exterior } \\
\left({ }^{\circ} \mathrm{C}\right)\end{array}$ & $\begin{array}{c}\text { Interio } \\
\boldsymbol{r}\left({ }^{\circ} \mathbf{C}\right)\end{array}$ \\
\hline \multirow{4}{*}{ Lm35 } & $\mathrm{C}$ & $8: 30$ & 17 & 27.0 \\
\cline { 2 - 5 } & $\mathrm{M}$ & $11: 30$ & 22 & 28.5 \\
\cline { 2 - 3 } & $\mathrm{M}$ & $14: 30$ & 24 & 28.0 \\
\cline { 2 - 3 } & $\mathrm{C}$ & $17: 30$ & 21 & 27.5 \\
\hline
\end{tabular}




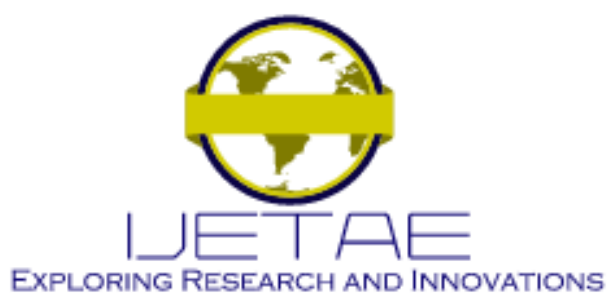

International Journal of Emerging Technology and Advanced Engineering

Website: www.ijetae.com (E-ISSN 2250-2459, Scopus Indexed, ISO 9001:2008 Certified Journal, Volume 11, Issue 11, November 2021)

After obtaining the temperature data, it was observed that the bulb turned on and off for short periods, which impaired the bulb's life. However, the wait time when the parameters are correct reduces these inconveniences.

Table 3 shows the humidity values obtained under the same conditions as in Table 2:

TABLE 3.

MEASURED HUMIDITY CONDITIONS

\begin{tabular}{|c|c|c|c|c|}
\hline \multirow{3}{*}{ Sensor } & \multirow{2}{*}{ Condition } & \multirow{2}{*}{ Time } & \multicolumn{2}{|c|}{} \\
\cline { 5 - 5 } & & & $\begin{array}{c}\text { Exterior } \\
(\boldsymbol{\%})\end{array}$ & $\begin{array}{c}\text { Interior } \\
(\boldsymbol{\%})\end{array}$ \\
\hline \multirow{3}{*}{ DHT11 } & $\mathrm{C}$ & $8: 30$ & 18 & 60.0 \\
\cline { 2 - 5 } & $\mathrm{T}$ & $11: 30$ & 27 & 68.0 \\
\cline { 2 - 5 } & $\mathrm{T}$ & $14: 30$ & 25 & 52.0 \\
\cline { 2 - 5 } & $\mathrm{C}$ & $17: 30$ & 17 & 57.0 \\
\hline
\end{tabular}

The percentage correction error in the temperature variable was calculated from formula (1), obtaining an error of $0.90 \%$, and it was observed that the humidity variable never exceeded the calibrated setpoint.

$$
\text { Percentage error }=[(A-B) / B] * 100 \%
$$

$A=$ Average of the measured variable

$\mathrm{B}=$ Real value

In addition, to determine the total power of the prototype, the independent consumption and the total consumption in watts were measured. First, the current measurement $\left(I_{n}\right)$ in milliamps $(\mathrm{mA})$ of each $5 \mathrm{v}$ consumer device was performed. Afterwards, the sum of those values will be multiplied by the working voltage. The result $\left(P_{D C}\right)$ understanding it as the power in direct current.

$$
P_{D C}=\left(\sum_{i=0}^{n} I_{n}\right) * 5
$$

$\mathrm{P}_{\mathrm{DC}}=$ Direct current power $(\mathrm{W})$

$\mathrm{I}_{\mathrm{n}}=$ Current in the $\mathrm{nth}$ device

Then the consumption of the $220 \mathrm{v}$ bulb was measured. Since it works in alternating current, it is necessary to calculate the active power by measuring the bulb's current, and it must be considered a fi coefficient, with an approximate value of 0.95 .

$$
\begin{gathered}
P_{A C}=V * I * \cos (\varnothing) \\
P_{A C}=220 * I * \cos (0.95) \\
P_{A C}=I * 219.969
\end{gathered}
$$

$\mathrm{P}_{\mathrm{AC}}=$ Power in alternating current $(\mathrm{W})$

$\mathrm{V}=$ Voltage $(\mathrm{V})$

$\mathrm{I}=$ Current $(\mathrm{A})$

Afterwards, the total power of the prototype was obtained, the sum of $P_{D C}$ and $P_{A C}$ in $\mathrm{kW}$ units must be made to facilitate the monetary calculation since this corresponds to the units used by the electrical service concessionaires in Peru.

$$
\mathrm{M}=\mathrm{I} * 219.969 * \mathrm{~B}
$$

$\mathrm{M}=$ Total amount $(\mathrm{S} /$.

$\mathrm{I}=$ Current $(\mathrm{A})$

$\mathrm{B}=$ Rate per $\mathrm{kW} / \mathrm{h}$ in the region $(\mathrm{kW} / \mathrm{h} \times \mathrm{S} /$.)

According to the study area, the price amount would be taken from the BT5B RESIDENTIAL rate option represented in equation (4) with variable $B$, which admits consumption less than $100 \mathrm{~kW} / \mathrm{h}$, corresponding to the majority of average households in the study area.

After obtaining the values and checking the correct control in the quail farm prototype, the system's total power consumption was obtained considering the continuous DC voltages at $5 \mathrm{~V}$ and alternating $\mathrm{AC}$ at $220 \mathrm{~V}$.

TABLE 4.

Power Measurements

\begin{tabular}{|c|c|c|c|}
\hline Component & $\begin{array}{c}\text { Type of } \\
\text { element }\end{array}$ & $\begin{array}{c}\text { Current } \\
(\boldsymbol{m} \boldsymbol{A})\end{array}$ & $\begin{array}{c}\text { Power } \\
(\boldsymbol{W})\end{array}$ \\
\hline $\begin{array}{c}\text { Arduino } \\
\text { Nano v3.0 }\end{array}$ & DC & 16.50 & 0.0825 \\
\hline $\begin{array}{c}\text { Temperature } \\
\text { sensor Lm35 }\end{array}$ & DC & 0.32 & 0.0016 \\
\hline $\begin{array}{c}\text { Humidity } \\
\text { sensor } \\
\text { DHT11 }\end{array}$ & DC & 2.90 & 0.0145 \\
\hline $\begin{array}{c}\text { Relay module } \\
\text { LCD 14x2 } \\
\text { with module } \\
\text { I2C }\end{array}$ & DC & 29.10 & 0.1455 \\
\hline Lamp & AC & $112.95^{*}$ & $24.8455^{*}$ \\
\hline Fan & DC & 170.50 & 0.8525 \\
\hline Humidifier & DC & 122.20 & 0.6110 \\
\hline Total & & 477.87 & 26.67 \\
\hline
\end{tabular}




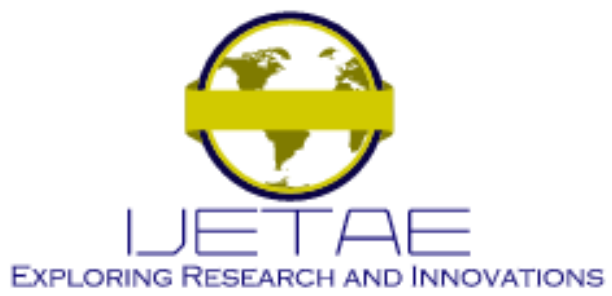

International Journal of Emerging Technology and Advanced Engineering Website: www.ijetae.com (E-ISSN 2250-2459, Scopus Indexed, ISO 9001:2008 Certified Journal, Volume 11, Issue 11, November 2021)

As shown in Table 4, the power consumed by Arduino and the other modules was measured without any connection. However, to compare the power consumed by the operating system, the measurement was developed with the sensor, relay and LCD modules connected and operating. This current was $71.82 \mathrm{~mA}$, corresponding to the total current of the Arduino, sensors, relay and LCD modules without the actuators, which is a value very close to the sum of the individual powers (72.22 $\mathrm{mA}$ ), thus checking that there is no consumption leakage in the system.

Likewise, as shown in Table 4, the total power used by the prototype corresponds to $0.02667 \mathrm{~kW} / \mathrm{h}$, which is lower than the consumption of another house appliance.

In addition, according to the price per kilowatt hour in the Arequipa region, it is S/. 0.6283. Therefore, the total cost to pay for the consumption of the quail farm system considering an average use of 8 hours a day would be S/. 4.02 per month, approximately one US dollar. If we compare that cost with the traditional use of a 100Watt bulb for an average of 12 hours, we would be paying S/. 22.61. This comparison is reflected in a saving of $82.22 \%$, from using a bulb of $100 \mathrm{~W}$ for 12 hours and the use of the proposed prototype, which optimizes the energy use.

\section{DISCUSSION AND CONCLUSIONS}

The prototype is reliable since it allows to house up to 25 quails in a suitable space and maintains the standards for the correct breeding of quails [18]. Besides, regarding the temperature variable, with the tests developed, it is appreciated that the temperature is in the appropriate range for the correct development of the quail; as mentioned in [32], the prototype would not harm the production of eggs caused by heat stress. Furthermore, the prototype reached similar result to other investigation [14].

A prototype farm capable of maintaining optimal temperature and humidity conditions for quail in the growth and egg-laying stage was completed and constructed unlike [12] which focuses on incubating quail eggs for 17 days. After carrying out the tests in environmental conditions of the Arequipa region for 8 hours, the total consumed power of $0.0267 \mathrm{~kW} / \mathrm{h}$ was calculated and saving $82.22 \%$ in energy consumption compared to using a $100 \mathrm{~W}$ bulb. The approach of this prototype is adapted to the needs of small families due to the number of quails.
Additionally, the correct construction of the farm is reflected in better autonomy. Also, this system is costeffective, which means that it is an accessible prototype for Arequipa families. Besides. this prototype had a correct performance since it presented a percentage error of $0.90 \%$ in the temperature control and did not exceed the critical humidity values indicated as the setpoint. The prototype also can be scalable and replicated in other regions of Peru to contribute and optimize quail breeding. It also has an industrial production projection since it includes the Arduino platform as a current and commercial microcontroller in automation systems.

As future work, the prototype with quail will be validated, and the system will be modified to add more bird growth stages so that the prototype can be used from when the bird is a quail chick until the last days of laying. In addition, it will seek to further reduce manufacturing costs with modular stages that are easy to install in farms already on the market.

\section{Acknowledgement}

This research was developed thanks to the support of the Universidad de Ciencias y Humanidades for its constant investment in research.

\section{REFERENCES}

[1] Ministerio de Economía y Finanzas, "Informe de actualización de proeciones macroeconómicas 2021-2024,” Apr. 2021. Accessed: May 02, 2021. [Online]. Available: https://www.mef.gob.pe/contenidos/pol_econ/marco_macro/IAPM_ 2021_2024.pdf.

[2] Instituto Nacional de Estadística e Informática, "Anuario Estadística Ambiental 2020," 2020. Accessed: Aug. 19, 2021. [Online]. Available:

https://www.inei.gob.pe/media/MenuRecursivo/publicaciones_digita les/Est/Lib1760/libro.pdf.

[3] S. nacional de metereología e H. del Perú, "Clima / Heladas y friajes," Preguntas frecuentes, 2021 https://www.senamhi.gob.pe/main.php?dp=arequipa\&p=heladas-yfriajes-preguntas (accessed Aug. 19, 2021).

[4] Ministerio de Educación, “Abrígate Perú - Heladas y friaje," 2021. http://www.minedu.gob.pe/heladas-friaje/friaje.php (accessed Aug. 18, 2021).

[5] J. O. Molina et al., "Design of an experimental bioclimatic module obtained from the analysis of thermal simulations for the community of Imata (4519 m a.s.1.), located in Arequipa, Perú," Inf. tecnológica, vol. 31, no. 2, pp. 173-186, Apr. 2020, doi: 10.4067/S071807642020000200173.

[6] D. Chavarria, R. Ramos, and C. Raymundo, "Development of a Hybrid Heating System Based on Geothermal-Photovoltaic Energy to Reduce the Impact of Frosts on Inhabitants of Rural Areas in the Ring of Fire, Southern Peru," in Smart Innovation, Systems and Technologies, Oct. 2018, vol. 140, pp. 131-139, doi: 10.1007/978-3030-16053-1_12. 


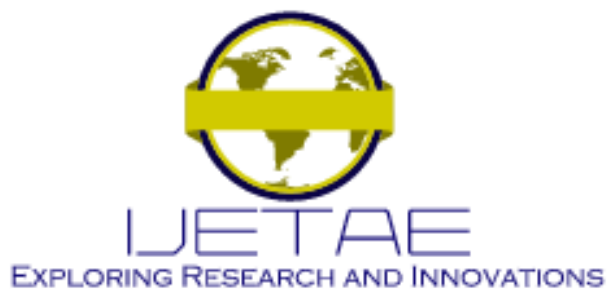

International Journal of Emerging Technology and Advanced Engineering

Website: www.ijetae.com (E-ISSN 2250-2459, Scopus Indexed, ISO 9001:2008 Certified Journal, Volume 11, Issue 11, November 2021)

[7] A. Jeke, C. Phiri, K. Chitiindingu, and P. Taru, "Nutritional compositions of Japanese quail (Coturnix coturnix japonica) breed lines raised on a basal poultry ration under farm conditions in Ruwa, Zimbabwe," http://www.editorialmanager.com/cogentagri, vol. 4, no. 1, p. 1473009, Jan. 2018, doi: 10.1080/23311932.2018.1473009.

[8] N. Sahin, F. Akdemir, C. Orhan, O. Kucuk, A. Hayirli, and K. Sahin, "Lycopene-enriched quail egg as functional food for humans," Food Res. Int., vol. 41, no. 3, pp. 295-300, Jan. 2008, doi: 10.1016/J.FOODRES.2007.12.006.

[9] C. Dussaillant et al., "Consumo de huevo y enfermedad cardiovascular: una revisión de la literatura científica," Nutr. Hosp., vol. 34, no. 3, pp. 710-718, 2017, doi: 10.20960/NH.473.

[10] D. Tolik, E. Poławska, A. Charuta, S. Nowaczewski, and R. Cooper, "Characteristics of egg parts, chemical composition and nutritive value of Japanese Quail eggs - A review," Folia Biol., vol. 62, no. 4, pp. 287-292, 2014, doi: 10.3409/FB62_4.287.

[11] S. G. Adabi, M. Ahbab, A. R. Fani, A. Hajbabaei, N. Ceylan, and R. G. Cooper, "Egg yolk fatty acid profile of avian species - influence on human nutrition," J. Anim. Physiol. Anim. Nutr. (Berl)., vol. 97, no. 1, pp. 27-38, Feb. 2013, doi: 10.1111/J.14390396.2011.01239.X.

[12] W. S. M. Sanjaya et al., "The development of quail eggs smart incubator for hatching system based on microcontroller and Internet of Things (IoT)," 2018 Int. Conf. Inf. Commun. Technol. ICOIACT 2018, vol. 2018-January, pp. 407-411, Apr. 2018, doi: 10.1109/ICOIACT.2018.8350682.

[13] K. A. Sitaram, K. R. Ankush, K. N. Anant, and B. R. Raghunath, "IoT based Smart Management of Poultry Farm and Electricity Generation," 2018 IEEE Int. Conf. Comput. Intell. Comput. Res. ICCIC 2018, Dec. 2018, doi: 10.1109/ICCIC.2018.8782308.

[14] J. F. Pushug Guacho, "Desarrollo de un prototipo de criadero automático con ambiente controlado destinado a mejorar los índices de producción de huevos en la coturnicultura," Universidad Politécnica Salesiana, 2017.

[15] L. C. Carvalho et al., "Genetic growth potential characterization in the Japanese quail: a meta-analysis," Animal, vol. 14, pp. s341s347, Jan. 2020, doi: 10.1017/S1751731120001202.

[16] S. A. Soliman, "Morphological and Histochemical Description of Quail Feather Development," Anat. Rec., vol. 303, no. 7, pp. 18651883, Jul. 2020, doi: 10.1002/AR.24276.

[17] D. Grieser et al., "Comparison of the Quality Adjusting of Nonlinear Models for Organs, Carcass and Body Components in Meat-Type (Coturnix Coturnix Coturnix) and Laying-Type (Coturnix Coturnix Japonica) Quail," Brazilian J. Poult. Sci., vol. 19, no. 4, pp. 701-710, Oct. 2017, doi: 10.1590/1806-9061-2016-0424.

[18] D. O. Grimaldos Pereira, "Guía para la producción de codornices y sus derivados," Universidad Cooperativa de Colombia, Bucaramanga, 2020.

[19] M. SAINT JALME and J. C. GUYOMARC'H, "Plumage development and moult in the European Quail Coturnix c. coturnix: criteria for age determination," Ibis (Lond. 1859)., vol. 137, no. 4, pp. 570-581, Oct. 1995, doi: 10.1111/J.1474919X.1995.TB03268.X.
[20] L. A. Tafur Culqui, "Rendimiento reproductivo de codornices japonesas (Coturnix coturnix japónica) de diferentes edades y pesos al incio del empadre," Universidad Nacional Agraria La Molina, 2017.

[21] J. López-Cordova, F. Sotelo-Valer, and E. Guerreros-Valdivia, "Cálculo del Potencial Eólico en las pampas de La Joya. Arequipa Perú,”2020, doi: 10.18687/LACCEI2020.1.1.317.

[22] SENAMHI, "Promedio de temperatura normal para AREQUIPA." https://www.senamhi.gob.pe/?p=pronostico-detalleturistico\&localidad $=0018$ (accessed Aug. 19, 2021).

[23] C. M. Álvarez Alfaro, "Evaluación de Mensuración de Temperatura Comparando Cuatro Tipos De Termómetros en Canes en el Distrito de Yanahuara, Arequipa - Perú 2018," Universidad Católica de Santa María, 2018.

[24] "Arduino Nano | Tienda oficial Arduino." https://store.arduino.cc/usa/arduino-nano (accessed May 19, 2021).

[25] V. Karanassios, "Sensors trends: Smaller, cheaper, smarter, faster and under wireless control," in FLEPS 2019 - IEEE International Conference on Flexible and Printable Sensors and Systems, Proceedings, Jul. 2019, pp. 1-4, doi: 10.1109/FLEPS.2019.8792272.

[26] M. Gergeleit, "Autotree: Connecting Cheap IoT Nodes with an Auto-Configuring WiFi Tree Network," in 2019 Fourth International Conference on Fog and Mobile Edge Computing (FMEC), Jun. 2019, pp. 199-203, doi: 10.1109/FMEC.2019.8795311.

[27] R. Abburi, M. Praveena, and R. Priyakanth, "TinkerCad - A Web Based Application for Virtual Labs to help Learners Think, Create and Make," J. Eng. Educ. Transform., vol. 34, no. 0, pp. 535-541, Jan. 2021, doi: 10.16920/JEET/2021/V34I0/157209.

[28] Arduino, “Arduino - Inicio," 2015. https://www.arduino.cc/ (accessed May 19, 2021).

[29] E. M. Khusnutdinova, O. A. Filina, A. N. Khusnutdinov, A. V. Yashagina, G. V. Osetinskiy, and N. K. Andreev, "Designing the Fault-Detection and Troubleshooting Tests For the Troubleshooting Target Flowchart," IOP Conf. Ser. Mater. Sci. Eng., vol. 915, no. 1, p. 012033, Sep. 2020, doi: 10.1088/1757-899X/915/1/012033.

[30] P. N. Crisnapati, I. N. K. Wardana, I. K. A. A. Aryanto, and A. Hermawan, "Hommons: Hydroponic management and monitoring system for an IOT based NFT farm using web technology," in 2017 5th International Conference on Cyber and IT Service Management (CITSM), Aug. 2017, pp. 1-6, doi: 10.1109/CITSM.2017.8089268.

[31] T. P. Santana et al., "Effect of prenatal ambient temperature on the performance physiological parameters, and oxidative metabolism of Japanese quail ( Coturnix coturnix japonica ) layers exposed to heat stress during growth," Sci. Reports 2021 111, vol. 11, no. 1, pp. 111, May 2021, doi: 10.1038/s41598-021-89306-0.

[32] M. Alagawany, M. R. Farag, M. E. A. El-Hack, and A. Patra, "Heat stress: effects on productive and reproductive performance of quail," https://doi.org/10.1017/S0043933917000782, vol. 73, no. 4, pp. 747-755, Oct. 2019, doi: 10.1017/S0043933917000782. 